\title{
The Transformation of Financial System and Its Impact on Consumers: Case Study of Pakistan
}

\author{
Najia Saqib ${ }^{1}$
}

\begin{abstract}
The banking industry has undergone profound changes during the last decade. The most obvious change has been the large number of bank mergers, which have increased both the average size of banks and the area over which they operate. Other changes may also prove dramatic but are at this point just getting under way-the growth of e-banking and the combination of banking with other financial services, such as insurance and securities underwriting.The article discusses the recent changes in financial system are likely to benefit consumers.
\end{abstract}

JEL classification numbers: E44, G34, G21 and F36

Keywords: Financial system, Consolidation, E-Banking and Financial integration

\section{Introduction}

The banking industry has undergone profound changes during the last decade. The most obvious change has been the large number of bank mergers, which have increased both the average size of banks and the area over which they operate. Other changes may also prove dramatic but are at this point just getting under way-the growth of e-banking and the combination of banking with other financial services, such as insurance and securities underwriting.

Some analysts argue that the changes will benefit most communities by increasing the public's access to financial services and making it easier for banks to continue lending during regional economic downturns. Others argue that the changes will end up hurting many communities, especially smaller ones, because the large organizations created by mergers will be uninterested in serving small customers and will siphon off funds from smaller markets to lend in big cities.

\footnotetext{
${ }^{1}$ Dr., Assistant Professor, Prince Sultan University, Riyadh-Kingdom of Saudi Arabia.
} 
To shed light on the debate, this article focuses on the two groups that are most likely to be affected by the transformation of financial system that are consumers. Before the recent changes, surveys consistently found that consumers relied heavily on local banks for their credit and payments needs. It stands to reason, therefore, that they would also be the groups most affected by any changes in local banking practices resulting from consolidation, e-banking, or financial integration.

The article concludes that the recent changes in financial system are likely to benefit consumers in most communities, as long as they remain free to choose between small and large banks for their banking services.

The first section of the article reviews the three major changes in the financial system consolidation, e-banking, and financial integration. The next section argue that these changes are likely to benefit consumers, provided small banks are available to fill any gaps in service or credit to smaller customers. The last section concludes that small banks face a major but not insurmountable obstacle in continuing to fill this role the increased difficulty of obtaining funds.

\section{Literature Review}

Banks all over the world have been effectively deploying information technology as an innovative resource to achieve speed, efficiency, cost reduction, customer service and competitive advantage. Technology enabled products and delivery channels offer value to customers providing them with anywhere, anytime, anyway banking to customers. Even in a developing country like India the banks have realized that in order to remain competitive and provide the best services to their customers they need to have the latest technology in place. These technological changes have been pioneered in India by foreign sector and private sector banks but now it is seen that the traditional banks in the public sector are also increasingly pursuing technology.

Several studies which had been done mainly in other countries have been examined to understand the pattern of usage of electronic banking services by bank customers. Lewis (1991) found that users mainly used ATMs for withdrawal of cash and obtaining account balances. Negative factors regarding ATM usage were concern over personal safety, lack of privacy and operational problems such as machine being regularly out of cash or out of order and cards getting stuck in it. In their study in Australia, Rugimbana and Iversen (1994) found that ATM customers mostly used it for cash withdrawal and conducted less than $50 \%$ of their transactions through it; hence they concluded that most users perceived ATMs to be just convenient cash dispensers, while the non-users preferred contact with human tellers and had a need for personal service.

A study conducted in UK on Direct Banking customers (Phone Banking) by Lockett and Littler (1997) found that risk averse households were less likely to adopt direct banking and households that used other technologies (ATMs and online shopping) were more likely to adopt direct banking. Al-Ashban and Burney (2001) after researching Saudi Arabian tele banking consumers concluded that tele-banking has resulted in substantial cost savings for the banks and has given rise to increasing convenience for the increasingly discerning consumers. They also found that customers tend to increase their usage of tele-banking services depending on their past experience. Jayawardhena and Foley (2000) from their work among UK banks found out that the advantages for banks through using e-banking as cost savings, increased customer base, mass customization 
and marketing \& communication opportunities, innovation and development of non-core businesses. They categorized e-banking functions into four: view-only functions, account control functions, applying for new services and reconciliation functions.

Mattila (2001) opined after studying Finnish bank customers that Experience with computers was a major driver for e-banking use. Polatoglu and Ekin (2001) found that those who use the e-banking services for the longest time or who use more of its services find e-banking to be very reliable. E-banking not only reduces operational costs to banks but also increases customer satisfaction and retention.

Bradley and Stewart (2002) concluded that the key drivers for bank adopting e-banking were the external factors such as competition and industry adoption, low risk, enhanced ability to deal with customers and the availability of technology. The key inhibitors were mostly internal like resistance to change, internal attitudes, internal resources and legal issues. The findings of research by Karjaluoto et al. (2002) amongst Finnish bank customers showed that 'prior experience' with computer and technology along with 'attitudes' towards computer, influence both attitude and behavior towards online banking. Gerrard and Cunningham (2003) who conducted a study among Singapore bank customers identified eight characteristics relating to the adoption of e-banking such as social desirability, compatibility, convenience, complexity, confidentiality, accessibility, economic benefits and PC proficiency as eight influential factors of adoption.

\section{Major Changes in the Banking System}

While always in a state of flux, the nation's financial system is now undergoing what is arguably the greatest transformation since the Great Depression. This change has taken three forms. First, banks have merged at an unprecedented pace during the last ten years. Second, banks and other financial companies have begun to offer their services over the Internet. And third, new legislation has opened up the doors to combining banking with other financial services.

\subsection{Consolidation}

Merger activity has subsided more recently, and some experts believe the decline is more than just a temporary pause. Some large banking companies have already achieved nationwide coverage, reducing their incentive to acquire more banks. Furthermore, to the extent Internet banking catches on, banking organizations keen on expanding may not have to depend on mergers to get bigger. Finally, some experts argue that acquisitions of small banks will not rebound because the mid-size companies that accounted for most of the small bank acquisitions in the 1980s and 1990s have largely disappeared from the scene. Even if merger activity does not return to previous levels, however, the large numbers of mergers that have already occurred have changed the banking system in important ways.

Both Banks and Non-Bank Financial Institutions (NBFIs) have witnessed around 50 cases of Mergers and Acquisitions (M\&As) involving more than 150 financial institutions since the year 2000. Notably, 8 of the 30 M\&A transactions involving commercial banks have been executed in CY06 alone. This suggests that the ongoing consolidation of the financial sector is well on its way to create new opportunities and challenges for the 
stakeholders of the financial sector. Importantly, this is not a phenomenon unique to Pakistan. Factors such as financial liberalization (deregulation and privatization), globalization of financial markets, advances in information technology, changing regulatory environment, and increasing pressure of shareholders to improve financial performance continue to play a vital role in shaping the financial landscape around the globe ${ }^{2}$.

Opportunities and challenges stemming from consolidation have a strong bearing on the stability of the financial sector. Specifically, consolidation bodes well for stability considerations if M\&As are able to create efficient and well-diversified financial institutions. On the other hand, risks may arise if they lead to the emergence of big conglomerates venturing into risky areas, and if issues related to 'too big to fail' start to emerge.

The main focus is on the consolidation of the banking sector, which is the predominant player as it constitutes around 71.8 percent share of the overall financial sector assets. The issues covered in this article relate to the causes of financial sector consolidation and the potential impacts of this consolidation on the structure and stability of the banking sector such as competition, financial risk profile, conduct of monetary policy, efficiency of financial institutions, and implications for SBP as the regulator/supervisor of the banking sector. It may be worth emphasizing at this stage that the estimation of partial impacts of financial sector consolidation is a difficult process, as a given change in any financial indicator used for this purpose is simultaneously affected by all other changes taking place in the financial sector, i.e. other than consolidation. It is our effort to focus on those indicators which can explain the possible impact of consolidation to a greater extent.

Table 1 indicates that a host of factors are responsible for M\&As in Pakistan. The most notable factor is the MCR, which is a reflection of the regulatory push for consolidation in the banking sector. It may be noted that such a regulatory strategy is not unique to Pakistan. International experience suggests that regulatory pressure is more prominent in emerging economies, while market pressure encourages this process in developed economies.

${ }^{2}$ For details, please see International Capital Markets Report, Developments, Prospects and Key Policy Issues, August 2001, IMF (Chapter V - Financial Sector Consolidation in Emerging Markets). 
Table 1: M\&As in the Banking Sector

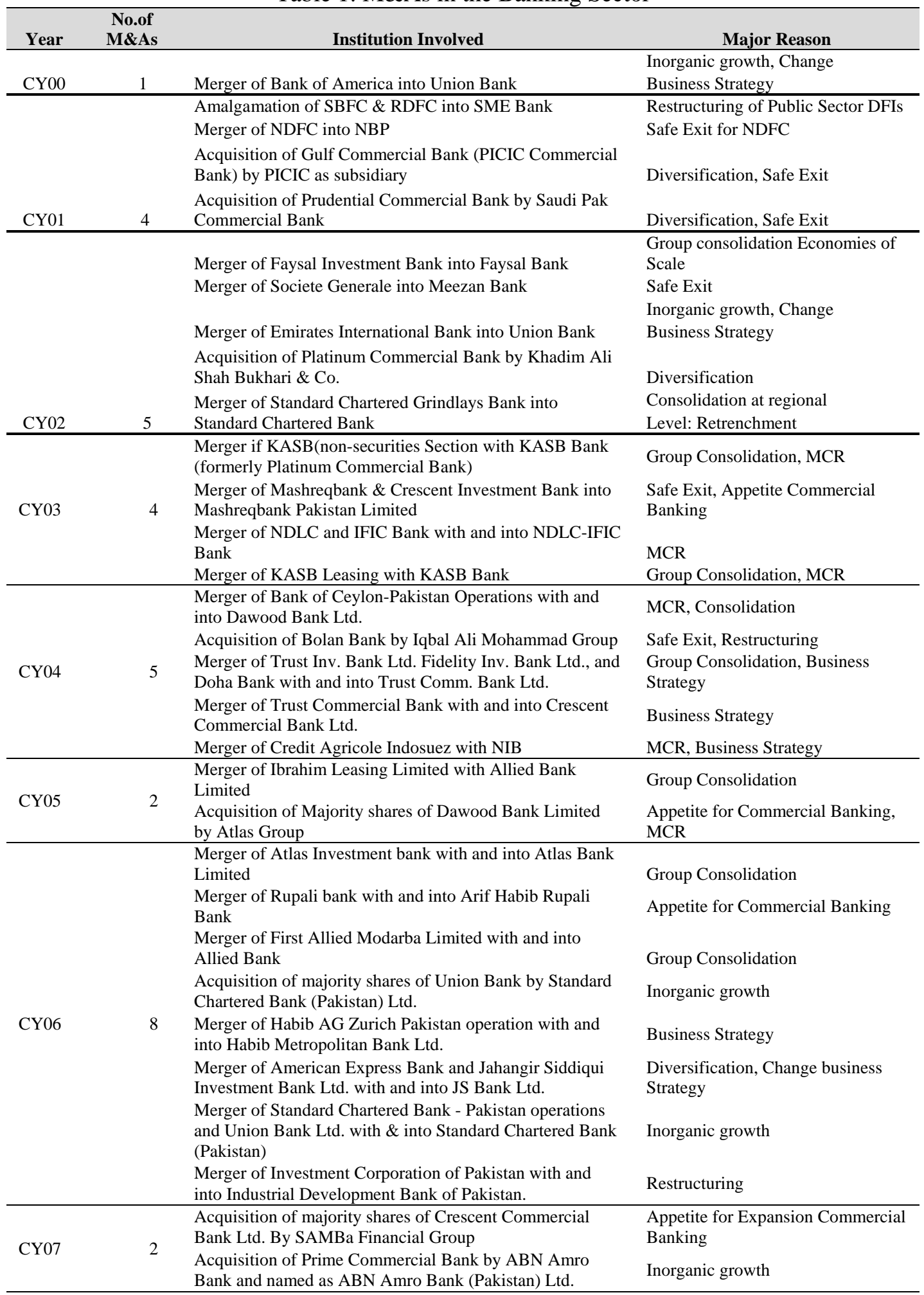

Source: Banking Policy and Regulations Department, SBP 


\subsection{E-Banking}

Another way banking is being transformed is through the growth of E-banking. Whereas mergers have been going on for some time and may even have peaked, this change is just getting under way. Several banks and thrifts had web sites, representing a third of all banks and thrifts. These are web sites through which customers can conduct business online for example, verify account information, transfer funds, pay bills, or apply for loans. While the number of banks with transactional web sites is still small, it has grown rapidly over the last few years a trend most experts expect to continue.

Numerous banking services through the technology platform have not only enhanced business volumes of banks and increased access to unbanked geographical regions, it has also brought about operational and cost efficiencies, he observed and added that more recently, information technology has brought about another revolutionary change in how banking will be conducted in the future; by bringing about the possibility of branchless banking, the whole concept of brick and mortar branch is changing.

In Pakistan, Electronic Banking (E-banking) is getting increasingly popular as the number and value of E-banking transactions in the country have shown a significant growth in the last few years. According to a Report titled 'Retail Payment Systems of Pakistan' (Paper-based and E-banking) of the State Bank of Pakistan, E-banking transactions were recorded increasing graph year by year.

It may be mentioned here that retail payments are mainly made by consumers and between commercial counterparties to purchase goods and services. At the retail level, most transactions use paper based instruments. However, electronic mode is also getting momentum with the passage of time. Retail payments in Pakistan are comprised of various paper-based and electronic instruments from conventional cheques to modern smart cards.

\subsubsection{Real Time Online Banking (RTOB) transactions}

The total number of Real Time Online Banking (RTOB) transactions increased every current year as compare to increase recorded previous year. Banks use RTOB channel for conducting various transactions which in fact constitute 94 percent of total e-Banking transactions value in the Pakistan ${ }^{3}$.

\footnotetext{
${ }^{3}$ Report on The Retail Payment Systems of Pakistan 2010, State bank of Pakistan
} 


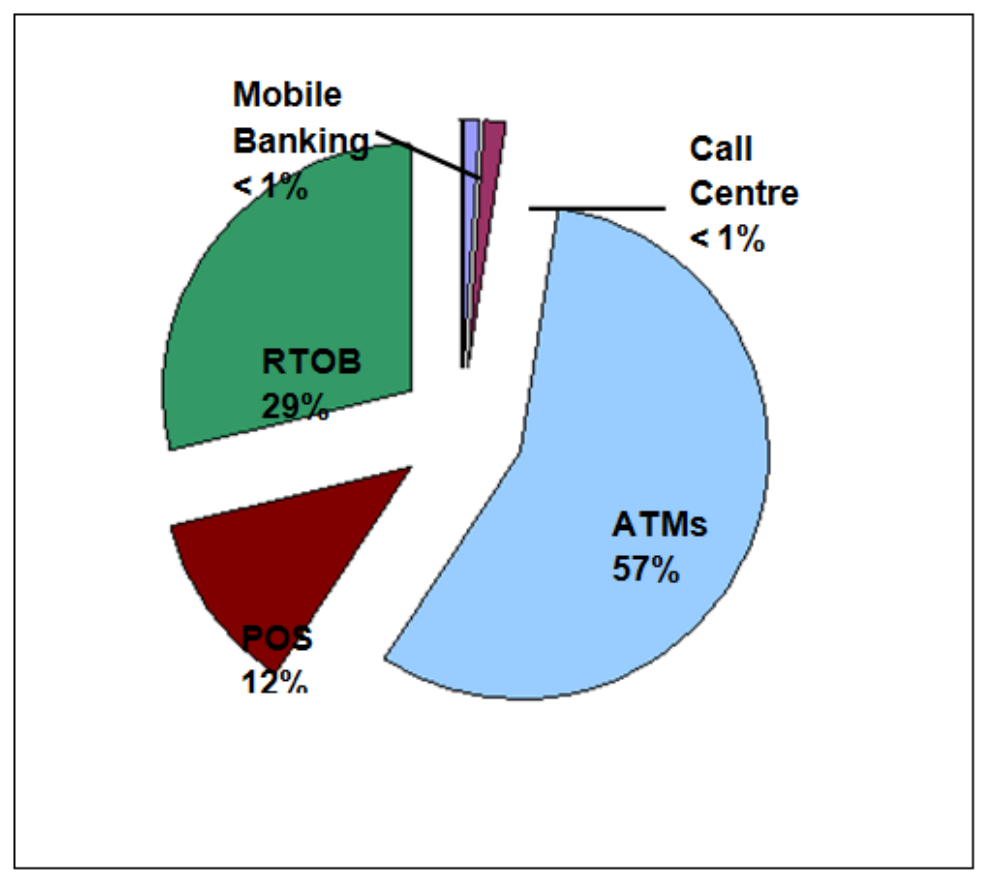

Figure 1: Share in e-banking (volume of transactions)

\subsubsection{Transactions through ATMs}

ATMs transactions during the year have continuously increased. Apart from cash withdrawal, ATMs are also used for inter/intra bank funds transfer, cash deposits, payment of utility bills etc. In Pakistan, on average, 72 transactions were executed per day per ATM share of volume of Transaction in E-Banking mention in Figure-A.

\subsubsection{POS (Point of Sale) Transactions}

The total number of POS machines/terminals has reached at 50,944 placed across the country on different merchant locations. The number of POS transactions have increased current year as compare to increase recorded in last year.

\subsubsection{Call Centre Banking}

Banking through Call Centre/Interactive Voice Response (IVR) is also included in the electronic banking channels. It also has increasing graph.

\subsubsection{Internet Banking}

Internet banking includes payments and electronic funds transfer (EFT). The funds transfer, however, is presently limited to intra bank account to account funds transfer except for a bank which offers interbank funds transfer facility through internet. Internet banking in Pakistan is growing slowly but at a steady pace. 


\subsubsection{Mobile Banking}

There are few banks which offer transactions through mobile. These transactions include payment through mobile (excluding utility bills payment), utility bills payment, $\mathrm{A} / \mathrm{C}$ to $\mathrm{A} / \mathrm{c}$ funds transfer and 3rd party A/c to A/C funds transfer.

\subsubsection{Internet Merchant Banking}

Transactions done through internet merchant account are part of Internet Merchant (IM) Banking. There were a total of 22 internet merchant accounts in 2010. Mostly service sector/NGOs are IM account holders. The number as well as amount of transactions done through internet merchant accounts is not consistent as transactions done are of seasonal nature and covers activities like air fares, college fee payments etc.

\subsubsection{Cross Border Transactions through E-Banking (ATM, POS, Internet)}

Cross border transactions include only those transactions which were executed using either an ATM / POS machine or Internet. ATM transactions include cash withdrawal through ATMs; the inflow of such transactions has increased in current year. The POS transactions include purchases of goods and services by the customers. The foreign merchants include names like eBay, Amazon, Google etc. Internet transactions also include payment of fee for foreign universities and online courses like ACCA, CIMA etc.

\subsection{Financial Integration}

Financial integration was particularly expedited in FY07 in which record high foreign portfolio investment was made in equity securities, both through the issuance of GDRs and in the stock market. Additionally, with the rising strength of the corporate sector and vigorous expansion plans, the central bank is in the process of initiating external commercial borrowing (ECB), which at the moment is approved on a transactional basis. This liberalization measure will provide an opportunity to the corporate sector to raise external loans for project finance, bonds floatation, structured finance and Islamic products.

Financial integration makes the economies more vulnerable and risk-prone. Policy errors and macroeconomic mistakes can be magnified by capital market reactions and generate crises of large proportions. But then these reactions also act as a powerful deterrent for the policy makers from indulging in irresponsible policies, low return pet projects and rent seeking by their political cronies

\section{Impact of the Changes on Consumers}

\subsection{Impact Analysis of the Consolidation Process}

The on-going process of mergers and acquisitions is driven by a host of factors including increasing minimum capital requirements, appetite for commercial banking, and diversification of businesses, change in business strategies, inorganic growth, and high profitability. Moreover, while these M\&As are taking place voluntarily, the role of supervisory authorities (SBP and SECP) remains supportive. 
The impact analysis of the consolidation process yields the following insights:

1. Structure of the banking sector has witnessed visible changes over the period of analysis. Local private banks have emerged as the dominating category.

2. Although the asset share of foreign banks has declined in the overall banking sector, equity holdings of foreign investors have increased.

3. Various concentration measures point towards increased competition in the banking sector. Specifically, the share of big five banks has declined and the share of second tier big five banks has increased. Moreover, indicators such as the H-index and coefficient of variation indicate a decline in concentration.

4. Impact of M\&As on efficiency indicators suggest that large institutions were able to benefit from M\&As to some extent, while these gains were not visible in case of small financial institutions.

5. There is no substantial change in financial risk at the institutional and aggregate level as a result of the consolidation process. Specifically, there is an indication of decline in financial risk at the individual institution level, due to gains from geographic and product diversification. On the other hand, there is no indication of an increase in contagion effect generally associated with M\&As. The primary reason for this seems to be that a large number of M\&As have generally involved weak and small banks and non-bank financial institutions.

6. The impact of M\&As on the conduct of monetary policy is gauged by looking at the minimum number of participants for the efficient market functioning of both the primary auction market and the market for OMOs. The results suggest that there is still considerable room for more M\&A transactions, as the minimum number of existing market participants are still considerably lower than the overall number of market participants.

7. As regulatory and supervisory requirements generally increase in response to crosscategory and cross-border M\&As, there is a need to put in place a strong coordinated supervisory framework in addition to the present coordination mechanism. This is particularly important in view of the expected changes in financial landscape in the near future.

\section{Impact of E-banking}

It was once thought that the main benefit to consumers of e-banking would be lower fees for banking services or higher rates on deposits. According to this view, the cost to banks of online transactions would be much lower than the cost of traditional transactions through a normal branch. As a result, consumers would be charged lower fees or paid higher deposit rates if they banked online instead of going to a branch office. Proponents of this view pointed to the example of online brokers, who charge investors much less for trading stocks than either discount brokers or traditional full-commission brokers (Marks, 1999).

The hope that online banking would result in lower fees or higher deposit rates for consumers has not been realized, mainly because banks themselves have not reaped significant cost savings (Hitt, Frei, and Harker; Long, 1999). One reason banks have not enjoyed substantial cost reductions are that they have had to make large investments in infrastructure and customer support. Another reason is that online banking has not enabled banks to cut back on their traditional delivery channels as much as initially 
hoped. Specifically, consumers have demonstrated that they strongly prefer the "click and bricks" approach to pure online banking, forcing banks to maintain their costly branch networks.

Rather than lower fees, the main benefit of online banking to consumers is likely to be greater convenience. Through online accounts, for example, consumers can now pay their bills by creating a list of regular payees and then instructing the bank to make payments as they receive the bills, either by electronic funds transfer or paper check. Some banks have begun to offer consumers an even more convenient service called bill presentment. In this case, the bank collects the bills itself and transmits them to the consumer over the Internet, where the customer can review them along with his account balances and initiate payment as desired. Another online banking service that is not yet widely offered, but could prove highly convenient to consumers, is account aggregation. This service allows the customer to view his entire portfolio online, including accounts at other institutions, and to shift funds in and out of different investments.

\section{Impact of Financial Integration}

The passage of GLBA makes it easier for banking organizations to provide consumers with other financial services besides banking. Some of these services, such as the opportunity to purchase life insurance and property and casualty insurance, are currently provided by insurance companies and insurance agents. Other services, such as the ability to buy and sell individual stocks and shift funds into and out of mutual funds, are now provided by brokerage companies.

Allowing all these services to be provided by the same company could benefit consumers in two possible ways-through synergies on the production side or synergies on the consumption side (Santomero and Eckles, 2000). Production synergies exist when it is less costly for a single company to provide a group of financial services than for several companies to provide them, each specializing in a different service. For example, both banks and insurance companies may need to know something about their customers' overall financial condition. With a single company providing both banking and insurance services, the costs of acquiring such information only have to be incurred once, allowing the consumer to be charged lower prices. Consumption synergies arise when it is less time consuming or more convenient for the consumer to purchase different financial services from a single company than from a number of different companies. Such gains from onestop shopping accrue to the consumer directly, although they may be partly offset by the bank charging higher prices for services.

It is unclear that either of these synergies from financial integration will be big enough to benefit consumers significantly. Empirical studies have found little evidence of production synergies within the banking industry - for example, between lending and deposit-taking - casting some doubt on the existence of synergies between banking and other financial services. Studies have also found no evidence that customer are willing to pay more when banking services such as lending and deposit-taking are provided by the same bank than when they are provided by separate banks (Berger, Humphrey, and Palley). Furthermore, companies such as Sears that have offered consumers one-stop shopping for financial services in the past have met with little success, suggesting there were few synergies on either the production or the consumption side (Ferguson, 1998). 
Another reason for doubting that financial integration will have a big impact on consumers is that, thanks to the Internet, the benefits of one-stop shopping can be obtained without different financial services being provided by the same company (Barth, Brumbaugh, and Wilcox, 2000). As noted earlier, some banks, brokerage companies, and nonbank portals have begun to let their consumers use a single web site to access a variety of financial services offered by unrelated companies. Surveys also suggest that consumers who like one-stop shopping believe they will get a better deal if the services are provided by multiple institutions than by a single company (Newkirk, 2000).

\section{Conclusion}

The banking industry is undergoing three major changes - the consolidation of the institutions, the spread of e-banking, and the increased freedom to combine banking with other financial services. In assessing what these changes mean for local economies, this paper has focused on the consumers.

On the whole, consumers appear to be benefiting from the changes. Consolidation has not reduced competition in local banking markets very much, because most of the mergers have not been between banks in the same city or county. Large multistate banks appear to charge higher fees, but consumers who believe those fees are unjustified still have plenty of smaller banks to choose from. The spread of e-banking should also benefit consumers by reducing the time and inconvenience of banking transactions and, in very small communities, by providing access to banking services that might otherwise be unavailable.

It is less clear that combining banking with other financial services will benefit consumers. Conglomerates show no evidence of producing retail financial services at lower cost than specialists, and the Internet provides other ways for consumers to reap the benefits of one-stop shopping besides buying all their services from the same provider.

\section{References}

[1] Al-Ashban, A. A. and Burney, M. A.. Customer adoption of telebanking technology: the case of Saudi Arabia, International Journal of Bank Marketing, 19 (5), (2001), 191-200.

[2] Barth, James R., R. Dan Brumbaugh Jr., and James A. Wilcox. Policy Watch: The Repeal of Glass Steagall and the Advent of Broad Banking, Journal of Economic Perspectives, Spring. 2000

[3] Bradely, L. and Stewart, K.. A Delphi Study of the Drivers and Inhibitors of Internet Banking, International Journal of Bank Marketing, 20 (6), (2002), 250-260.

[4] Ferguson, Roger W. Some Observations on the Future of the Financial Services Sector and Related Public Policy Issues, Board of Governors, (1998).

[5] Gerrard, P., Cunningham, J. B. and Devlin, J. F. (2006). Why Consumers are not using internet banking: a qualitative study, Journal of Services Marketing, 20 (3), (2006), 160-168.

[6] Hitt. Lorin M., Francis X. Frei, and Patrick T. Harker.. How Financial Firms Decide on Technology, in Brookings-Wharton Papers on Financial Services, 1999. 
[7] Jayawardhena, C. and Foley, P. Changes in the Banking Sector- the case of internet banking in UK, Internet Research: Electronic Networking Applications and Policy,10 (1), (2000), 19-30.

[8] Karjaluoto, H., Mattila, M. and Pento, T.. Factors underlying attitude formation towards online banking in Finland, International Journal of Bank Marketing, 20 (6), (2002), 261-272.

[9] Lewis, B. R. Service quality: an international comparison of bank customers' expectations and perceptions, Journal of Marketing Management, 7 (1), (1991), 4762.

[10] Lockett, A. and Littler, D. The Adoption of Direct Banking Services, Journal of Marketing Management, 13 (8), (1997), 791-811.

[11] Marks, James.. The Impact of the Internet on Users and Suppliers of Financial Services, in Brookings-Wharton Papers on Financial Services. 1999.

[12] Mattila, M., Karjaluoto, H., and Pento, T.. Internet Banking Adoption Factors in Finland, Journal of Internet Banking and Commerce, (2001), 6 (1), e-journal, accessed through www.arraydev.com.

[13] Newkirk, Kristine M. “One-Stop Web Banking” Independent Banker, November. Rehm, Barbara A. (2000). "Reform Law Leaves Some Doubters,” American Banker, 2000.

[14] Polatoglu, V. N. and Ekin, S. An Emphirical Investigation of The Turkish Consumers' Acceptance of Internet Banking Services, International Journal of Bank Marketing, 19 (4), (2001), 156-165.

[15] Rugimbana, R. and Iversen, P. Perceived attributes of ATMs and their marketing implications, International Journal of Bank Marketing, 12 (2), (1994), 30-35.

[16] Santomero, Anthony M., and David L. Eckles.“The Determinants of Success in the New Financial Services Environment,” Federal Reserve Bank of New York, Economic Policy Review, 2000. 